\title{
Hematological profile of sickle cell disease in Chhattisgarh
}

\author{
Ashish Verma ${ }^{1}$, Basant Maheshwari ${ }^{1 *}$, Debapriya Rath ${ }^{2}$
}

\begin{abstract}
${ }^{1}$ Department of Pharmacology, Pandit Jawahar Lal Nehru Memorial Medical College, Raipur, Chhattisgarh, India ${ }^{2}$ Department of Biochemistry, Pandit Jawahar Lal Nehru Memorial Medical College, Raipur, Chhattisgarh, India
\end{abstract}

Received: 22 December 2019

Revised: 25 February 2020

Accepted: 28 February 2020

\section{*Correspondence:}

Dr. Basant Maheshwari,

Email: dhiraj.bhawnani@gmail.com

Copyright: (C) the author(s), publisher and licensee Medip Academy. This is an open-access article distributed under the terms of the Creative Commons Attribution Non-Commercial License, which permits unrestricted non-commercial use, distribution, and reproduction in any medium, provided the original work is properly cited.

\section{ABSTRACT}

Background: Sickle cell disease hemoglobinopathy gets inherited in autosomal recessive pattern. In sickle cell disease substitution of amino acid valine for glutamic acid at the sixth position on beta globin chain takes place resulting in sickled hemoglobin which is a hemoglobin tetramer.

Methods: A prospective observational study was conducted in the Sickle Cell Institute, Raipur, India, and Department of Pharmacology in collaboration with Department of Biochemistry, Pt. J.N.M. Medical College, Raipur, Chhattisgarh, India, from February 2018 to June 2018. Patients included were in the steady state for a long period of time without any symptoms related to sickle cell disease or any other diseases which could affect hematological parameters. Subjects transfused in the last three months were excluded. Student $t$ test and Pearson Correlation Coefficient test was done on stat pages and socscistatistics calculators. P-value $<0.05$ was considered as statistically significant.

Results: A total of 50 subjects of sickle cell disease homozygous (SS) were studied for hematological parameters. The mean age $\pm \mathrm{SD}$ of 50 subjects were $13.3 \pm 9.24$ years. Out of 50 subjects, 35 were males and 15 were females. Total RBC count, mean corpuscular volume (MCV), mean corpuscular haemoglobin $(\mathrm{MCH})$ and mean corpuscular hemoglobin concentration (MCHC) was low in present study. Significant inverse correlation was found in females between $\mathrm{HbA} 2$ and $\mathrm{HbF}, \mathrm{p}=0.01$, while it was insignificant and negatively correlated in males being 0.23 .

Conclusions: Sickle cell disease homozygous is a common and challenging health problem of Chhattisgarh population.

Keywords: Chhattisgarh, Hematological profile, Sickle cell disease

\section{INTRODUCTION}

Sickle cell disease hemoglobinopathy gets inherited in autosomal recessive pattern. ${ }^{1}$ In sickle cell disease substitution of amino acid valine for glutamic acid at the sixth position on beta globin chain takes place resulting in sickled hemoglobin which is a hemoglobin tetramer. Sickled haemoglobin $(\mathrm{HbS})$ which is produced is low soluble and polymerized when deoxygenated. ${ }^{2}$ Sickle cell disease in India is characterized by higher levels of foetal hemoglobin $(\mathrm{HbF})$, more frequent alpha thalassemia, higher total hemoglobin and lower retic counts and persistence of spleenomegaly compared to Jamaican homozygous sickle cell disease. ${ }^{3}$ In contrast to this benign picture, studies from central India report severe disease (defined as $>3$ bone pain crises, $>3$ transfusions/year) in $30 \%$ children. ${ }^{4}$ In a study done for finding sickle cell anemia prevalence in Kanker, Dantewada and Raigarh districts of Chhattisgarh, the prevalence of sickle cell trait (HbAS) was $10.6 \%$ and of sickle cell disease (HbSS) and inconclusive band was $0.66 \% .^{5}$ There are scarcity of data in the current topic. With the above background, the present study was conducted to assess the haematological profile of sickle cell disease patients. 


\section{METHODS}

A prospective observational study was conducted in the Sickle Cell Institute, Raipur, Chhattisgarh and Department of Pharmacology in collaboration with Department of Biochemistry, Pt. J.N.M. Medical College, Raipur, Chhattisgarh, India from February 2018 to June 2018. Study permission was obtained from Institutional Ethical Committee. Patients included were in the steady state for a long period of time without any symptoms related to sickle cell disease or any other diseases which could affect hematological parameters. Subjects transfused in the last three months were excluded. All the sickle cell disease patients are under hydroxyurea therapy at present. Blood samples were collected in the Sickle Cell Institute OPD, Raipur. Five $\mathrm{ml}$ of blood was collected in EDTA from patients. Complete blood count (CBC) was measured using hematology autoanalyser. Quantitative assessment of $\mathrm{HbS}$ and $\mathrm{HbF}$ was done by high performance liquid chromatography (HPLC) technique, using variant II. Data was recorded on a predesigned proforma and was analyzed on Excel Sheet 2007. Student t test and Pearson Correlation Coefficient test was done on Statpages and Socscistatistics calculators. $\mathrm{P}$ value $<0.05$ was considered as statistically significant.

\section{RESULTS}

A total of 50 subjects of sickle cell disease homozygous (SS) were studied for hematological parameters. The mean age $\pm \mathrm{SD}$ of 50 subjects were $13.3 \pm 9.24$ years. Out of 50 subjects, 35 were males and 15 were females. Male outnumbered females and the sex ratio was $2.3: 1$. The age of the subjects ranged from 2 years to 43 years. Mean age \pm SD of males were $12.25 \pm 9.99$ years while mean age $\pm \mathrm{SD}$ of females were $15.73 \pm 6.90$.

Table 1: Hematological comparison between male and female sickle cell disease patients $(n=50)$.

\begin{tabular}{|c|c|c|c|c|}
\hline $\begin{array}{l}\text { Hematological } \\
\text { parameters }\end{array}$ & $\begin{array}{l}\text { Male }(\mathbf{n}=35) \\
\text { Mean } \pm \text { SD }\end{array}$ & $\begin{array}{l}\text { Female }(\mathbf{n}=15) \\
\text { Mean } \pm \text { SD }\end{array}$ & $\begin{array}{l}\text { Total }(\mathbf{n}=\mathbf{5 0}) \\
\text { Mean } \pm \text { SD }\end{array}$ & $\begin{array}{l}\text { P value } \\
\text { (significant/insignificant) }\end{array}$ \\
\hline $\mathrm{Hb}(\mathrm{g} / \mathrm{dl})$ & $8.18 \pm 1.94$ & $7.88 \pm 1.95$ & $8.09 \pm 1.93$ & 0.61, Insignificant \\
\hline Het $(\%)$ & $24.84 \pm 6.29$ & $24.38 \pm 5.03$ & $24.70 \pm 5.89$ & 0.80, Insignificant \\
\hline RBC (million/mm³) & $2.92 \pm 0.87$ & $2.91 \pm 0.61$ & $2.92 \pm 0.79$ & 0.96 , Insignificant \\
\hline $\operatorname{MCV}(\mathbf{f l})$ & $87.16 \pm 8.42$ & $83 \pm 11.86$ & $85.92 \pm 9.65$ & 0.16 , Insignificant \\
\hline MCH (pg) & $28.47 \pm 4.07$ & $26.65 \pm 4.38$ & $27.92 \pm 4.21$ & 0.16, Insignificant \\
\hline MCHC (g/dl) & $32.87 \pm 4.07$ & $32.23 \pm 3.77$ & $32.64 \pm 3.95$ & 0.60, Insignificant \\
\hline $\mathrm{HbF}(\%)$ & $18.79 \pm 5.21$ & $16.86 \pm 6.76$ & $18.21 \pm 5.72$ & 0.27 , Insignificant \\
\hline HbA2 (\%) & $2.26 \pm 0.37$ & $2.60 \pm 0.97$ & $2.36 \pm 0.62$ & 0.07, Insignificant \\
\hline
\end{tabular}

Hematological profile of study subjects are shown in the Table 1. There were more males as compared to females in our study. Total hemoglobin is low in sickle cell disease patients in present study, more so in females in comparison to males, although the difference is not statistically significant, $\mathrm{p}=0.61$. Total $\mathrm{RBC}$ count, mean corpuscular volume (MCV), mean corpuscular haemoglobin $(\mathrm{MCH})$ and mean corpuscular hemoglobin concentration (MCHC) were low in present study. In this study RBC count in males was $2.92 \pm 0.87$, while in females it was $2.91 \pm 0.61$, a significant positive correlation was found between total hemoglobin and total RBC count, $p$-value for male was $<0.00001$ i.e. significant and was 0.0023 in females Table 2. Mean MCV in males was $87.16 \pm 8.42 \mathrm{fl}$, while it was $83 \pm 11.86 \mathrm{fl}$ in females, difference in male and females was insignificant, $p$ value being 0.16. Correlation between MCV and total hemoglobin in both sexes were not statistically significant, $\mathrm{p}$ value for males was 0.08 and for females it was 0.96. Mean MCHC in males was $32.87 \pm 4.07$ and in females it was $32.23 \pm 3.77 \mathrm{~g} / \mathrm{dl}$, with $\mathrm{p}$ value between the two sexes being 0.60 , i.e. insignificant. Mean HbA2 values in males and females were $2.26 \pm 0.37$ and $2.60 \pm 0.97 \%$ respectively.
Table 2: Correlation between various hematological parameters in males and females.

\begin{tabular}{|llll|}
$\begin{array}{l}\text { Hematological } \\
\text { parameters }\end{array}$ & $\mathbf{r}$ & P value & $\begin{array}{l}\text { Significant/ } \\
\text { insignificant }\end{array}$ \\
\hline Males & & & \\
\hline Hb vs RBC & 0.7231 & 0.0023 & Significant \\
\hline Hb vs MCV & -0.0144 & 0.96 & Insignificant \\
\hline MCV vs HbA2 & -0.6267 & 0.01 & Significant \\
\hline HbA2 vs HbF & -0.6265 & 0.01 & Significant \\
\hline MCV vs HbF & 0.2197 & 0.43 & Insignificant \\
\hline Females & & & \\
\hline Hb vs RBC & 0.8693 & $<0.00001$ & Significant \\
\hline Hb vs MCV & -0.2965 & 0.0842 & Insignificant \\
\hline MCV vs HbA2 & -0.2081 & 0.2305 & Insignificant \\
\hline HbA2 vs HbF & -0.3321 & 0.05 & Insignificant \\
\hline MCV vs HbF & -0.0864 & 0.62 & Insignificant \\
\hline
\end{tabular}

It was observed in present study that between MCV and $\mathrm{HbA} 2$ a significant negative inverse correlation exists in the females, p-value being 0.01 and an insignificant negative correlation was seen in the males, with $\mathrm{p}$ value was 0.23 . Mean $\mathrm{HbF}$ value in males was $18.79 \pm 5.21$ and it was $16.86 \pm 6.76$ in females. No significant correlation between $\mathrm{MCV}$ and $\mathrm{HbF}$ in females, p value being 0.43 and in males, $\mathrm{p}$ value 0.62 was found in present study. 
Significant inverse correlation was found in females between $\mathrm{HbA} 2$ and $\mathrm{HbF}$, p value was 0.01 , while it was insignificant and negatively correlated in males, $\mathrm{p}=0.23$.

\section{DISCUSSION}

In the present study hematological profile of 50 cases of sickle cell disease patients are being reported from Chhattisgarh, India. Males outnumber females in 35:15 ratio. Male predominance could be due to the gender bias in our society, in which females pay less attention towards their illness and are discriminated from males. Age of females varied from 4 to 27 years and their mean \pm SD being $15.73 \pm 6.90$ years. Age of males varied from 2 to 43 years and the mean \pm SD being 12.25 \pm 9.99 years.

Total mean \pm SD of haemoglobin $(\mathrm{g} / \mathrm{dl})$ in both the sexes was $8.09 \pm 1.93$. When compared between males and females, it was $8.18 \pm 1.94$ in males and $7.88 \pm 1.95$ in females, lower in females than males, $\mathrm{p}$ value being 0.61 , insignificant (Table 1). The difference between hemoglobin levels of males and females were due to the androgenic effect in males and menstruation in females. Low total hemoglobin could be due to increased hemolysis and frequent recurrent infections in the sickle cell disease patients. Similar haemoglobin values were seen in studies done by Jadhav et al, Nagose et al, Rao et al and Boasiako et al, while in study by Kohchale et al it was low. ${ }^{6-10}$

Total Hct(g/dl) was $24.70 \pm 5.89$, it was $24.84 \pm 6.29$ in males and $24.38 \pm 5.03$ in females, $p$ value being 0.80 , i.e. insignificant. Similar values of Hct was found in the studies of Boasiako et al, while higher hematocrit was found in the studies of Jadhav et al, Jawalkar et al, Rao et al and Nagose et al, while it was lower in study by Kohchale et al. ${ }^{6-11}$

Total RBC counts (million/ $/ \mathrm{mm}^{3}$ ) was low in our study, it was $2.92 \pm 0.79$. It was $2.92 \pm 0.87$ in males and was $2.91 \pm 0.61$ in females, $\mathrm{p}$ value being 0.96 , insignificant. Similar values of RBC counts were seen in the study by Boasiako et al. ${ }^{9}$ Higher RBC counts were reported in studies by Jawalkar et al, Nagose et al, Jadhav et al and Rao et al, whereas lower RBC counts were seen in the study by Kohchale et al. ${ }^{6-8,10,11}$ Significant positive correlation was found in present study in both sexes between total RBC count and total hemoglobin, $\mathrm{p}$ value being 0.0023 , in males and $<0.00001$ in females. These values were similar to the study by Shrikhande et al. ${ }^{12}$

Mean \pm SD of mean corpuscular volume (MCV), was $85.92 \pm 9.65$ and it was $87.16 \pm 8.42$ in males and $83 \pm 11.86$ in females, $\mathrm{p}$ value between the two sexes being 0.16 , insignificant. Similar values of MCV were seen in studies by Nagose et al and Boasiako et al. ${ }^{7,9}$ Lower MCV values were reported in the studies by Rao et al, Jawarkar et al and Kohchale et al whereas higher MCV values were reported by Jadhav et al. ${ }^{6,8,10,11}$ An insignificant and negative correlation was seen in present study in both sexes between haemoglobin and mean corpuscular volume, with a $\mathrm{p}$ value of 0.96 in males and 0.08 in females, similar were findings in study by Shrikhande et al. ${ }^{12}$ In sickle cell disease Vit $\mathrm{B}_{12}$ and folic acid are at a critical borderline levels and increased demands on erythropoesis due to the chronic haemolytic process leads to macrocytosis and higher MCV. Lower MCV values in some of the studies could be due to coexisting Iron deficiency anemia and alpha thalassemia. ${ }^{6}$

Mean \pm SD of mean corpuscular hemoglobin (pg) $(\mathrm{MCH})$ was $27.92 \pm 4.21$, it was $28.47 \pm 4.07$ in males and $26.65 \pm 4.38$ in females. The $\mathrm{p}$ value between males and females came out to be 0.16 , insignificant. Similar values of $\mathrm{MCH}$ was seen in the studies by Nagose et al, Boasiako et al, Rao et al and Jadhav et al. ${ }^{6-9}$ Lower values in $\mathrm{MCH}$ were reported by Kohchale et al and Jawarkar et al. ${ }^{9,10}$

Mean \pm SD of mean corpuscular haemoglobin concentration $(\mathrm{MCHC})(\mathrm{g} / \mathrm{dl})$ was $32.64 \pm 3.95$, it was $32.87 \pm 4.07$ in males and $32.23 \pm 3.77$ in females, $p$ value between females and males came out to be 0.60 , again insignificant. Similar were values of $\mathrm{MCHC}$ reported in studies by Nagose et al, Boasiako et al, Rao et al and Jawarkar et al. ${ }^{7-9,11}$ Higher MCHC were reported in the studies by Kohchale et al and lower MCHC was reported in study by Jadhav et al. ${ }^{6,10}$

Mean $\pm \mathrm{SD}$ of $\mathrm{HbF}(\%)$ was $18.21 \pm 5.72$, it was $18.79 \pm 5.21$ in males and $16.86 \pm 6.76$ in females. The $\mathrm{p}$ value of $\mathrm{HbF}$ between males and females came out to be 0.27 i.e. insignificant. Almost similar values were seen in the studies by Jadhav et al. ${ }^{6}$ Lower $\mathrm{HbF}(\%)$ value was reported in study by Rao et al. ${ }^{8}$ An insignificant but positive correlation was seen in present study between $\mathrm{MCV}$ and $\mathrm{HbF}$ in males with $\mathrm{p}$ value being 0.43 , whereas an insignificant but negative correlation was found in this study between MCV and $\mathrm{HbF}$ in females with $\mathrm{p}$ value being 0.62. Insignificant but positive correlation was reported from study by Shrikhande et al in both the sexes between $\mathrm{MCV}$ and $\mathrm{HbF}$. ${ }^{12}$

Mean \pm SD of $\mathrm{HbA} 2$ was $2.36 \pm 0.62$, it was $2.26 \pm 0.37$ in males while it was $2.60 \pm 0.97$ in females, $p$ value being 0.07 , insignificant. Significant and negative correlation was seen in present study between MCV and $\mathrm{HbA} 2$ in males with $\mathrm{p}$ value being 0.01 . It was insignificant and negatively correlated in females in our study with $p$ value being 0.23. Significant negative correlation was found in study by Shrikhande et al, in both sexes, thus in respect of males present study is similar to the study by Shrikhande et al. ${ }^{12}$ Insignificant and negative correlation was seen in our study between $\mathrm{MCV}$ and $\mathrm{HbA} 2$ in females with $\mathrm{p}$ value being 0.23 , thus in this regards our study differs from study by Shrikhande et al. ${ }^{12}$ Significant and negative correlation was seen in males in present study between $\mathrm{HbA} 2$ and $\mathrm{HbF}$ with $\mathrm{p}$ value being 0.01 , similar were findings in study by Shrikhande et al in males. ${ }^{12}$ 
Insignificant and negative correlation was seen in our study in females, between $\mathrm{HbA} 2$ and $\mathrm{HbF}$, with p value of 0.05 , while in study by Shrikhande et al they reported significant and negative correlation between $\mathrm{HbA} 2$ and $\mathrm{HbF}$ in females, thus our study differs from study by Shrikhande et al in this regards. ${ }^{12}$

\section{CONCLUSION}

Present study revealed low levels of hemoglobin, hematocrit and RBC count in sickle cell disease homozygous population of Chhattisgarh. A higher level of foetal hemoglobin was found in both sexes in present study. Difference in hematologic parameters was seen between male and female sickle cell disease homozygous population in our study, but the difference was not statistically significant. Large scale studies are required further in the area for guiding the clinicians for the better management of sickle cell disease and for defining a baseline hematologic profile of sickle cell disease in the region.

Funding: No funding sources Conflict of interest: None declared

Ethical approval: The study was approved by the Institutional Ethics Committee

\section{REFERENCES}

1. Keikhaei B, Yousefi H, Bahadoram M. Hydroxyurea: clinical and hematological effects in patients with sickle cell anemia. Global $J$ Health Sci. 2016;8(3):252.

2. Platt OS. Hydroxyurea for the treatment of sickle cell anemia. N Engl J Med. 2008;358:1362-9.

3. Kar BC, Satapathy RK, Kulozik AE, Kulozik M, Sirr $\mathrm{S}$, Serjeant BE, et al. Sickle cell disease in Orissa State, India. Lancet. 1986;328(8517):1198-201.

4. Jain D, Italia K, Sarathi V, Ghosh K, Colah R. Sickle cell anemia from Central India. Indian Pediatr. 2012;49:911-3.
5. Panigrahi S, Patra PK, Khodiar PK. The screening and morbidity pattern of sickle cell anemia in Chhattisgarh. Indian J Hematol Blood Transfus. 2015;31(1):104-9.

6. Jadhav AJ, Vaidya SM, Bhagwat VR, Ranade AR, Vasaikar M. Haematological profile of adult sickle cell disease patients in North Maharashtra. WIMJOURNAL. 2016;3:1.

7. Nagose VB, Rathod SS. Hematological profile of sickle cell anemia subjects in Central India: a cross sectional analysis. Ann Pathol Lab Med. 2018;5(1):A87-91.

8. Rao SS, Goyal JP, Raghunath SV, Shah VB. Hematological profile of sickle cell disease from South Gujarat, India. Hematol Rep. 2012;4:e8.

9. Antwi-Boasiako C, Ekem I, Abdul-Rahman M, Sey F, Doku A, Dzudzor B, Dankwah GB, Otu KH, Ahenkorah J, Aryee R. hematological parameters in ghanaian sickle cell disease patients. J Blood Med. 2018;9:203.

10. Kohchale SR, Raja IA. Hematological profile of sickle cell anemic subjects from Gadchiroli District, Maharashtra. Int J Life Sci. 2015;A3:153-6.

11. Jawarkar A, Bhatia V. A study of HPLC patterns in patients of sickle cell anemia with analysis of red cell parameters. Int J Res Med Sci. 2018;6(7):2390-5.

12. Shrikhande AV, Dani AA, Tijare JR, Agrawal AK. Hematological profile of sickle cell disease in central India. Indian J Hematol Blood Transfus. 2007;23(34):92-8.

13. Patra PK, Tripathi S, Khodiar P, Sablania P, Keshari JR, Dalla AR. Epidemiology of sickle cell disease in state of Chhattisgarh. Indian J Public Health Res Dev. 2010;1(2):64-8.

Cite this article as: Verma A, Maheshwari B, Rath D. Hematological profile of sickle cell disease in Chhattisgarh. Int J Basic Clin Pharmacol 2020;9:5525. 